\title{
Increased Levels of Soluble Tumor Necrosis Factor- $\alpha$ Receptors in Serum from Pregnant Women and in Serum and Urine Samples from Newborns
}

\author{
RIGMOR AUSTGULEN, NINA-BEATE LIABAKK, EGIL LIEN, AND TERJE ESPEVIK \\ Department of Pediatrics, University Hospital of Trondheim [R.A.], Institute of Cancer Research, University \\ Medical Center, [R.A., N-B.L., E.L., T.E.], and UNIGEN, Center for Molecular Biology, University Medical \\ Center [N-B.L., E.L.], N-7005 Trondheim, Norway
}

\begin{abstract}
Secretion of soluble cytokine receptors has been suggested as a mechanism of regulating cytokine activity in vivo. In this study, the presence of soluble receptors for tumor necrosis factor- $\alpha$ (TNF- $\alpha)$ in serum samples from pregnant women and newborn babies was examined by using $\mathrm{TNF}-\alpha$ receptor-specific immunoassays. Serum from pregnant women contained the $55-\mathrm{kD}$ TNF- $\alpha$ receptor $555[6.4 \mu \mathrm{g} / \mathrm{L}$, interquartile range, i.e. the difference between the 25 th and 75 th percentile, (IQR) 7.2 $\mu \mathrm{g} / \mathrm{L}$, whereas p55 was not detected in control sera from nonpregnant, fertile women. The levels of p55 were also elevated in serum from newborns $(3.2 \mu \mathrm{g} / \mathrm{L}, \mathrm{IQR} 0.7 \mu \mathrm{g} /$ L). Furthermore, first-voided urine from newborns contained high levels of p55 $(44.6 \mu \mathrm{g} / \mathrm{L}$, IQR $96.6 \mu \mathrm{g} / \mathrm{L})$. The concentration of p55 in the neonatal period was significantly higher than that of children later in childhood $(p<$ $0.05)$. The concentration of p55 was $7.3 \mu \mathrm{g} / \mathrm{L}$, IQR 13.8 $\mu \mathrm{g} / \mathrm{L}$, in urine samples from a group of preschool children $(1 \mathrm{mo}<$ age $<5 \mathrm{y})$ and $6.9 \mu \mathrm{g} / \mathrm{L}$, IQR $2.9 \mu \mathrm{g} / \mathrm{L}$, in urine samples from children in a higher age group $(5 \mathrm{y}<$ age $<$ $10 \mathrm{y})$. The concentration of the $75-\mathrm{kD}$ TNF- $\alpha$ receptor in urine did not differ significantly between the different age groups studied. The elevated p55 serum levels of pregnant women and neonates are suggestive of a pregnancy-associated release of soluble receptors. The high concentration of p55 in neonatal urine may reflect a postpartum elimination of soluble receptors shed during pregnancy. Further studies are needed to determine the origin and physiologic implications of the soluble TNF- $\alpha$ receptors in pregnancy. (Pediatr Res 33: 82-87, 1993)
\end{abstract}

\section{Abbreviations}

TNF, tumor necrosis factor

TNFR, tumor necrosis factor receptor

p55, the extracellular domain of the TNFR with a molecular mass of $55 \mathrm{kD}$

$\mathrm{p} 75$, the extracellular domain of the TNFR with a molecular mass of $75 \mathrm{kD}$

$\mathrm{R} / \mathrm{p55}$, the ratio between the concentration of soluble $\mathrm{p55}$ $(\mu \mathrm{g} / \mathrm{L})$ and the concentration of protein in urine $(\mu \mathrm{g} / \mathrm{L})$

$R / p 75$, the ratio between the concentration of soluble $p 75$ $(\mu \mathrm{g} / \mathrm{L})$ and the concentration of protein in urine $(\mu \mathrm{g} / \mathrm{L})$

Received April 14, 1992; accepted September 1, 1992.

Correspondence and reprint requests: Rigmor Austgulen, University of Trondheim, Institute of Cancer Research, University Medical Center, N-7005 Trondheim, Norway.

Supported by the Norwegian Research Council for Science and Humanities (NAVF) and the Norwegian Cancer Society.
IQR, the interquartile range, i.e. the difference between the 25 th and the 75 th percentile

$B$, biotinylated

$r$, recombinant

Considerable attention has been paid to the influence of cytokines in human pregnancy, and it is now well established that several cytokines have the potential to regulate growth and differentiation of trophoblasts at the fetoplacental unit in addition to the immunoactivities usually ascribed to them (1-3). TNF- $\alpha$, a polypeptide cytokine produced primarily by mononuclear phagocytes $(4,5)$, has been detected in placenta $(6-8)$, amniotic fluid (6), and decidua (6). Recent observations suggest that local TNF- $\alpha$ may contribute to the regulation of cell proliferation at the uteroplacental unit; DNA synthesis of trophoblasts is inhibited by TNF- $\alpha(9,10)$. However, the detection of TNF- $\alpha$ at the fetoplacental unit is somewhat surprising because it is well known that TNF- $\alpha$ mediates effects that might be considered threatening to the well-being of the fetus; i.e. TNF- $\alpha$ is probably an important mediator in transplantation rejection $(11,12)$, and animal studies suggest that placental injury may be caused by TNF- $\alpha$ (13). Furthermore, TNF- $\alpha$ is apparently involved in premature pregnancy termination and abortion in mice $(14,15)$. In humans, elevated TNF- $\alpha$ levels in amniotic fluid are associated with infections and premature onset of parturition $(16,17)$.

The biological effects of TNF- $\alpha$ are mediated through its interaction with high-affinity receptors on target cells $(18,19)$. There are two molecular species of TNFR $(20-25)$, the $55-\mathrm{kD}$ TNFR protein, p55, and the 75-kD TNFR protein, p75. Each species also exists as soluble molecules $(26,27)$ that are probably shed from cells expressing TNFR on their surfaces (28), a phenomenon that has been demonstrated in activated neutrophils (29). The soluble TNFR specifically bind TNF- $\alpha(26,30)$. Thus, due to their ability to compete with the cell surface receptors for TNF- $\alpha$, soluble TNFR may function as inhibitors of TNF- $\alpha$ bioactivity $(26,30,31)$. Accordingly, secretion of specific, soluble membrane receptors could serve as a mechanism for regulating cytokine activity in vivo $(32,33)$.

Previously, we have reported elevated levels of p55 in urine samples from pregnant women (34), suggesting that shedding of soluble TNFR may be a mechanism of regulating TNF- $\alpha$ activity in pregnancy. One purpose of the present study was to determine whether the pregnant state implies that $\mathrm{p} 55$ are shed into the circulation of the pregnant woman. The second purpose was to determine whether the soluble receptors are restricted to the maternal organism or whether the fetus also is exposed to the 
shed TNFR. Fetal urine influences the composition of amniotic fluid (34), and we have previously reported that amniotic fluid contains high levels of soluble TNFR (35). Accordingly, this study included an examination of the first-voided urine from newborns for the presence of TNFR. In addition, levels of p55 in neonatal serum samples were assessed.

Maternal and neonatal serum samples contained elevated levels of soluble p55, as did first-voided urine from newborn babies. Thus, the data presented in this article, together with previous observations (35), suggest that a pregnancy-associated shedding of p55 takes place. The present study suggests that the soluble receptors are distributed throughout the maternal as well as the fetal organism.

\section{MATERIALS AND METHODS}

Serum samples. Blood was obtained by venipuncture from 28 pregnant women and from 10 nonpregnant women at fertile age. All pregnant women were in spontaneous labor, and all pregnancies were considered normal. Peripheral blood was also obtained by venipuncture from 15 newborns at the Neonatal Department during the first $24 \mathrm{~h}$ of life. The blood was allowed to clot at room temperature for $1-3 \mathrm{~h}$; after centrifugation, the serum was stored at $-20^{\circ} \mathrm{C}$ until assayed.

Urine collection. To determine whether soluble TNFR might be released from the fetus via urine, first-voided urine was collected from 70 healthy, newborn babies (46 boys, 23 girls) delivered at term. We have previously shown that there are no systematic changes in urine TNFR concentration during a 24-h period (35), and therefore the urine samples were collected whenever obtained during the first 24-h period after delivery.

To study the TNFR elimination in the perinatal period, the concentration of soluble TNFR in urine samples from nine healthy newborns was determined on $\mathrm{d} 1,3$, and 5 after delivery. All babies were born at term, and the urine samples were collected at any time during the indicated $24 \mathrm{~h}$.

First morning urine samples from 40 children at different ages were collected to obtain information about urine elimination of soluble TNFR during childhood. All children were patients at the Children's Department at the Regional Hospital during the last 4 mo of 1991. Urine samples included in the study were randomly taken from those samples brought to the laboratory for routine examination. The diagnoses of the children included in this part of the study are given in Table 1 . The children were divided into three groups, each group determined by the age of the children: group $\mathrm{A}(n=8), 1 \mathrm{~d} \leq$ age $\leq 1 \mathrm{mo}$; group $\mathrm{B}(n=$ $22), 1$ mo $<$ age $\leq 5 \mathrm{y}$; and group $\mathrm{C}(n=10), 5 \mathrm{y}<$ age $\leq 10 \mathrm{y}$ (Table 1). After collection, all urine samples were frozen at $-20^{\circ} \mathrm{C}$ until assayed.

Informed consent was obtained from the women/mothers to collect the materiais included in the study. Peripheral blood was taken from newborn babies at the Neonatal Department. For ethical reasons, neonatal serum could be obtained only if venipuncture was to be performed for other medical reasons. The study was approved by the Local Committee for Human Research.

Immunoassay for detection of soluble TNFR in urine. Immunoassays have been established for the detection of p55 and p75 in urine as described by Liabakk et al. (36). The immunoassays are based on pairs of MAb directed against different epitopes of p55 and p75 (21). Briefly, immunoplates were coated with MAb against either p55 (htr MAb) or p75 (utr MAb), samples were added, and bound TNFR were detected by using B htr MAb or $\mathrm{B}$ utr MAb, respectively (21). Bound B MAb were detected with a streptavidin-peroxidase complex (21). Absorbance was measured at $492 \mathrm{~nm}$.

Urine samples were passed through an Amicon filter (Amicon Corp., Danvers, MA) with a $10-\mathrm{kD}$ cutoff before addition to the immunoplates. This filtration caused a 10 -fold concentration of urine samples.
Table 1. Characteristics of sick children included in study*

\begin{tabular}{|c|c|c|c|c|c|}
\hline Case & Diagnosis & $\begin{array}{l}\text { Age } \\
\text { (mo) }\end{array}$ & $\begin{array}{c}\mathrm{p} 55 \\
(\mu \mathrm{g} / \mathrm{L})\end{array}$ & $\begin{array}{c}\mathrm{p} 75 \\
(\mu \mathrm{g} / \mathrm{L})\end{array}$ & $\begin{array}{l}\text { Protein } \\
(\mathrm{mg} / \mathrm{L})\end{array}$ \\
\hline 1 & Laryngitis & 48.0 & 7.4 & 83.5 & 959 \\
\hline 2 & Bronchial asthma & 24.0 & 34.9 & 41.8 & 748 \\
\hline 3 & Reduced appetite & 20.0 & 19.9 & 10.8 & 259 \\
\hline 4 & Nephrotic syndrome & 78.0 & 6.1 & 5.0 & 864 \\
\hline 5 & Lymphadenopathy & 114.0 & 8.8 & 34.3 & 706 \\
\hline 6 & Bronchial asthma & 16.0 & 20.3 & 18.9 & 270 \\
\hline 7 & Viral infection & 84.0 & 6.6 & 20.1 & 528 \\
\hline 8 & Abdominal pain & 72.0 & 9.4 & 24.6 & 586 \\
\hline 9 & Viral infection & 21.0 & 6.9 & 41.5 & 982 \\
\hline 10 & Malabsorption & 60.0 & 18.8 & 3.3 & 376 \\
\hline 11 & Tonsillitis & 84.0 & 7.5 & 3.4 & 252 \\
\hline 12 & Abdominal pain & 60.0 & 6.5 & ND & 161 \\
\hline 13 & Bronchial asthma & 60.0 & 7.8 & 23.2 & 853 \\
\hline 14 & Lymphadenopathy & 42.0 & 10.8 & 5.2 & 361 \\
\hline 15 & Inguinal hernia & 3.0 & 6.5 & 33.7 & 788 \\
\hline 16 & Laryngitis & 17.0 & 7.1 & 78.3 & 1298 \\
\hline 17 & Hydrothorax & 0.8 & 19.5 & 5.5 & 234 \\
\hline 18 & Tonsillitis & 96.0 & 6.1 & 1.5 & 40 \\
\hline 19 & Hyperbilirubinemia & 0.1 & 98.4 & 74.4 & 946 \\
\hline 20 & Nephrotic syndrome & 102.0 & 18.6 & 8.7 & 292 \\
\hline 21 & Neuroblastoma & 42.0 & 29.0 & 10.3 & 352 \\
\hline 22 & RDS & 0.2 & 46.5 & 53.4 & 829 \\
\hline 23 & RDS & 0.2 & 53.6 & 45.6 & 599 \\
\hline 24 & $\mathrm{BPD}$ & 3.0 & 4.9 & 14.7 & 742 \\
\hline 25 & Bronchial asthma & 18.0 & ND & 20.9 & 893 \\
\hline 26 & Hypoglycemia & 0.03 & 55.8 & 48.4 & 527 \\
\hline 27 & Laryngitis & 72.0 & 3.6 & 101.1 & 1830 \\
\hline 28 & Epilepsy & 12.0 & 7.2 & 52.0 & 540 \\
\hline 29 & Hypospadias & 0.1 & 40.5 & 163.0 & 867 \\
\hline 30 & Viral infection & 15.0 & 19.3 & 255.9 & 2451 \\
\hline 31 & Bronchial asthma & 48.0 & ND & 160.9 & 1493 \\
\hline 32 & Intoxication & 48.0 & 3.0 & 111.9 & 479 \\
\hline 33 & Laryngitis & 4.0 & 5.4 & 2.8 & 458 \\
\hline 34 & Anal atresia & 1.1 & 57.3 & 83.5 & 959 \\
\hline 35 & Tonsillitis & 6.0 & 6.9 & 3.8 & 136 \\
\hline 36 & RDS & 0.5 & 46.8 & 14.9 & 359 \\
\hline 37 & Fever convulsions & 33.0 & 22.6 & 16.6 & 628 \\
\hline 39 & Diabetes mellitus & 72.0 & 7.1 & 4.9 & 172 \\
\hline 40 & Septicemia & 0.1 & 134.6 & 41.6 & 1340 \\
\hline RA & Diabetes insipidus & 78.0 & 6.7 & ND & 147 \\
\hline
\end{tabular}

* Children under study were patients from Children's Department. First-morning urine was randomly obtained, and the urine samples were examined for $\mathrm{p} 55, \mathrm{p} 75$, and protein. The numbers represent the measured level in urine from each individual. ND, not detected; RDS, respiratory distress syndrome; BPD, bronchopulmonary dysplasia. The detection limit of the TNFR immunoassay was $0.6 \mu \mathrm{g} / \mathrm{L}$.

The specificity of the immunoassays was controlled by preincubation of the concentrated urine with $10 \mathrm{mg} / \mathrm{L}$ of different cytokines (human TNF- $\alpha$, human TNF- $\beta$, and human interferon- $\gamma$ ). Only TNF- $\alpha$, and to a lesser degree TNF- $\beta$, inhibited the TNFR signals from urine samples (36). These observations suggest that the immunoassays are specific for unoccupied TNFR in urine.

Immunoassay for detection of p55 in serum. The signals obtained when serum samples were added to the immunoassay described above were not inhibited when rTNF- $\alpha$ was added, indicating a nonspecific interaction. Thus, modifications of the immunoassay were done to assay serum samples. Immunoplates (Maxisorp, Nunc, Roskilde, Denmark) were coated with the p55specific MAb IV 4E, which detects an epitope on p55 outside the binding of TNF- $\alpha$ (Lien E, Liabakk N-B, Espevik T, manuscript in preparation). The MAb was diluted in PBS, and $100 \mu \mathrm{L}$ of antibody were added to each well in the concentration $10 \mathrm{mg} /$ L. Immunoplates were incubated for $12 \mathrm{~h}$ at $4^{\circ} \mathrm{C}$. After blocking with $0.5 \%$ BSA (RIA grade, Sigma Chemical Co., St. Louis, MO) 
for $1 \mathrm{~h}$ at $37^{\circ} \mathrm{C}$, wells were washed three times with PBS containing $0.1 \%$ Tween 20 (Sigma Chemical Co.) and $100 \mu \mathrm{L}$ of different dilutions of serum were added and incubated for $12 \mathrm{~h}$ at $4^{\circ} \mathrm{C}$. Because MAb IV 4E and TNF- $\alpha$ bind to different epitopes of p55, bound receptor was detected by adding $50 \mu \mathrm{g} / \mathrm{L} \mathrm{B} \mathrm{rTNF-} \alpha$ (TNF- $\alpha$-Biotin, Boehringer Mannheim, Germany) in PBS with $0.1 \%$ Tween 20 and $2 \%$ FCS (Gibco, Biocult, Glasgow, Scotland) to the wells. Immunoplates were incubated for $1 \mathrm{~h}$ at $37^{\circ} \mathrm{C}$ in humidity. After washing, bound B rTNF- $\alpha$ was detected with streptavidin-biotin-peroxydase complex using o-phenylenediamine as substrate (Dakopatts, Glostrup, Denmark). The reaction was stopped with $2 \mathrm{NH}_{2} \mathrm{SO}_{4}$. The absorbance was measured at $492 \mathrm{~nm}$ with a Titertek Multiscan Plus MKII (Flow, Boggio, Switzerland). The binding of B rTNF- $\alpha$ was abolished when an excess $(5 \mathrm{mg} / \mathrm{L})$ of rTNF was added to the assay, showing that the binding of B rTNF- $\alpha$ was not caused by an unspecific binding of biotin to the immunoplates.

The absorbance values obtained in the p55 and p 75 assays for urine and serum samples were compared to the absorbance of reference standards of p55 and p75 in recombinant forms (F. Hoffmann-La Roche, Basel, Switzerland). Results are expressed in $\mu \mathrm{g} / \mathrm{L}$. The detection limit for the immunoassay applied for analysis of urine samples was $0.6 \mu \mathrm{g} / \mathrm{L}$ concentrated urine. The detection limit for the assay with MAb IV $4 \mathrm{E}$ was $0.3 \mu \mathrm{g} / \mathrm{L}$ serum.

Protein concentration. To determine whether the levels of TNFR in urine were caused by changes reflected in urine protein concentration, protein concentration in all urine samples was determined. The protein concentration was determined by Biorad protein assay (Biorad Laboratories, Münich, Germany), the analysis being performed after the urine had been passed through the Amicon filter.

Statistical analysis. The distribution of TNFR in urine samples collected from the different groups of children showed a marked right-side skew with potentially high outliers. The median is therefore used as a measure of central tendency of all variables, and the variability is expressed as the IQR. TNFR concentrations in urine from different groups were compared by Kruskal-Wallis one-way analysis of variance. The Mann-Whitney test was used for comparison between pairs of groups.

$p$ values less than 0.05 were considered statistically significant.

\section{RESULTS}

Detection of 555 in serum from pregnant women and newborn babies. The soluble 55-kD TNFR was detected in sera from all pregnant women in spontaneous labor (Fig. 1); the average p55 concentration of the pregnant group was $6.4 \mu \mathrm{g} / \mathrm{L}, \mathrm{IQR} 7.2 \mu \mathrm{g} /$

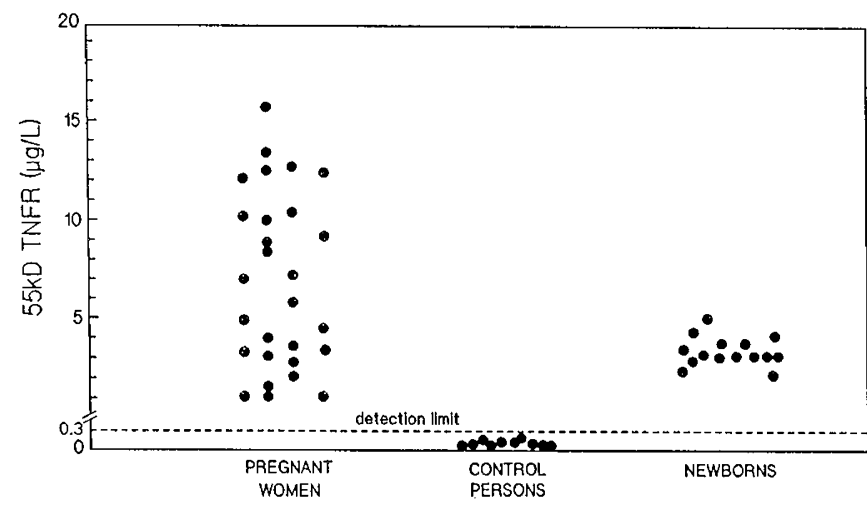

Fig. 1. Serum concentrations of the $55-\mathrm{kD}$ TNFR in samples of peripheral blood from pregnant women in spontaneous delivery at term, from newborn babies, and from nonpregnant controls. Each data point represents the measured level in serum from one individual. The receptors were detected in an immunoassay, and the detection limit of the assay is indicated by the dotted line.
L. Serum samples from newborn babies also contained increased levels of p55 (Fig. 1). The average TNFR concentration in serum for the group of newborns was $3.2 \mu \mathrm{g} / \mathrm{L}$, IQR $0.7 \mu \mathrm{g} / \mathrm{L}$. No p55 was detected in serum samples from nonpregnant controls (Fig. 1).

Detection of $p 55$ and $p 75$ in urine from newborn babies. Firstvoided urine from newborns contained both molecular species of the TNFR at high levels (Table 2). The average concentration of 555 was $44.6 \mu \mathrm{g} / \mathrm{L}, \mathrm{IQR} 96.6 \mu \mathrm{g} / \mathrm{L}$, and the average concentration of $\mathrm{p} 75$ was $64.8 \mu \mathrm{g} / \mathrm{L}$, IQR $122.9 \mu \mathrm{g} / \mathrm{L}$, in urine samples from healthy babies delivered at term. The urine protein concentration in the newborn group was $1767 \mathrm{mg} / \mathrm{L}$, IQR $1426 \mathrm{mg} / \mathrm{L}$. There were no significant differences between the concentrations of $\mathrm{p} 55, \mathrm{p} 75$, or protein in urine samples from girls and boys (Table 2).

Changes in urine TNFR concentration during the perinatal period. Urine samples from a group of nine healthy babies, obtained on d 1, 3, and 5 after delivery, were examined to study the TNFR elimination postpartum. The concentration of $\mathrm{p} 55$ in urine samples on $\mathrm{d} 5$ after delivery was significantly lower $(p<$ 0.05 ) than that on $\mathrm{d} 1$ and on $\mathrm{d} 3$ (Table 3 ). However, the calculated ratios $(\mathrm{R} / \mathrm{p} 55)$ between the concentrations of $\mathrm{p} 55$ and urine protein concentrations did not differ significantly between the days studied. Thus, we conclude that the observed changes in p 55 concentration may partly be caused by 1 ) the physiological dehydration that usually occurs during the first days postpartum; and 2) the increased fluid intake, and thus secondarily, urine dilution, which takes place approximately $5 \mathrm{~d}$ after delivery (37). The urine levels of p75 did not differ significantly on the days compared (Table 3); neither did the urine protein concentration (Table 3 ) or the ratio $(\mathrm{R} / \mathrm{p} 75)$ between the concentration of $\mathrm{p} 75$ and urine protein (numbers not shown) differ.

Changes in urine TNFR concentration during childhood. The concentration of $\mathrm{p} 55$ in urine was highest in the neonatal period when different age groups of children were compared (Fig. 2). Urine samples from children in group A (see Materials and Methods) contained significantly $(p<0.01)$ higher levels of $\mathrm{p} 55$ $(50.2 \mu \mathrm{g} / \mathrm{L}$, IQR $45.8 \mu \mathrm{g} / \mathrm{L})$ than those of group B $(7.3 \mu \mathrm{g} / \mathrm{L}$, IQR $13.8 \mu \mathrm{g} / \mathrm{L})$ and group C $(6.9 \mu \mathrm{g} / \mathrm{L}, \mathrm{IQR} 2.9 \mu \mathrm{g} / \mathrm{L})$ (Fig. 2). The concentration of $\mathrm{p} 75$ did not differ significantly between group A $(47.0 \mu \mathrm{g} / \mathrm{L}, \mathrm{IQR} 47.6 \mu \mathrm{g} / \mathrm{L})$, group B $(22.1 \mu \mathrm{g} / \mathrm{L}, \mathrm{IQR}$ $49.6 \mu \mathrm{g} / \mathrm{L})$, or group C $(6.9 \mu \mathrm{g} / \mathrm{L}$, IQR $24.1 \mu \mathrm{g} / \mathrm{L})$; neither did the protein concentration differ significantly between group $\mathrm{A}$ (715 mg/L, IQR $529 \mathrm{mg} / \mathrm{L})$, group B (685 mg/L, IQR $551 \mathrm{mg} /$

Table 2. Concentration of soluble TNFR (p55 and p75) and protein in first-voided urine from healthy babies delivered at term*

\begin{tabular}{cccc}
\hline & $\mathrm{p} 55(\mu \mathrm{g} / \mathrm{L})$ & $\mathrm{p} 75(\mu \mathrm{g} / \mathrm{L})$ & $\begin{array}{c}\text { Protein } \\
(\mathrm{mg} / \mathrm{L})\end{array}$ \\
\hline Boys $(n=46)$ & $49.3(106.8)$ & $67.0(122.9)$ & $2015(1452)$ \\
Girls $(n=24)$ & $23.4(41.7)$ & $61.7(147.2)$ & $1719(1540)$ \\
\hline
\end{tabular}

* Results are given as the median of the group. Numbers in parentheses express the variability as the IQR.

Table 3. Time course of concentration of soluble TNFR ( $p 55$ and $p 75)$ and protein in neonatal urine during perinatal period*

\begin{tabular}{ccrr}
\hline & & & $\begin{array}{c}\text { Protein } \\
(\mathrm{mg} / \mathrm{L})\end{array}$ \\
\hline $1 \ddagger$ & $109.2(160.6)$ & $91.3(80.1)$ & $2557(2454)$ \\
3 & $184.8(177.9)$ & $112.0(56.3)$ & $4610(5707)$ \\
5 & $21.7(41.3)$ & $32.6(71.0)$ & $746(1067)$ \\
\hline
\end{tabular}

* Results are given as the median of the group. Numbers in parentheses express the variability as the IQR.

$\dagger$ Urine samples were obtained at each of the given time points from nine healthy babies delivered at term.

$\$$ The first $24 \mathrm{~h}$ after delivery are defined as d 0 . d 1, d 3, and d 5 indicate the $24-\mathrm{h}$ periods after delivery corresponding to their number. 


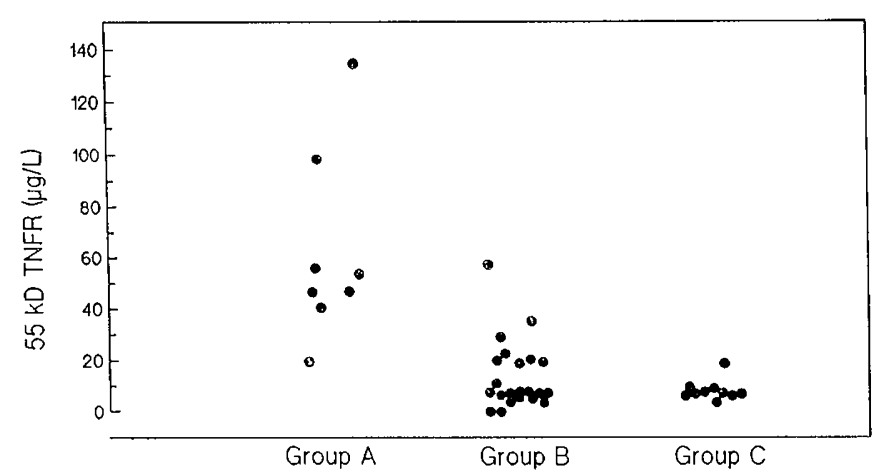

Fig. 2. Levels of the 55-kD TNFR (p55) in urine samples obtained from children at different ages (Table 1). The children were divided into groups determined by age: group A, $1 \mathrm{~d}<$ age $\leq 1 \mathrm{mo}$; group B, 1 mo $<$ age $\leq 5 \mathrm{y}$; and group $\mathrm{C}, 5 \mathrm{y}<$ age $\leq 10 \mathrm{y}$. Each data point represents the value measured in urine from one individual. The numbers of each value are given in Table 1.

L), or group C $(410 \mathrm{mg} / \mathrm{L}, \mathrm{IQR} 580 \mathrm{mg} / \mathrm{L})$. Furthermore, R/ p55 was higher $(p<0.01)$ in group A $\left(9.5 \times 10^{-5}\right.$, IQR $0.5 \times$ $\left.10^{-5}\right)$ than in group B $\left(0.1 \times 10^{-5}\right.$, IQR $\left.0.4 \times 10^{-5}\right)$ and group C $\left(0.2 \times 10^{-5}\right.$, IQR $\left.0.5 \times 10^{-5}\right)$. R/p 75 was not significantly different between groups (numbers not given).

Previous work has demonstrated that urine from normal healthy adults contains no $\mathrm{p} 55$, as assessed in the TNFR immunoassay (35). On the other hand, p75 is normally detected in urine from adults (35), suggesting that secretion of $\mathrm{p} 75$ may be a normal physiologic phenomenon.

\section{DISCUSSION}

In the present study, we report detection of elevated levels of the TNF- $\alpha$ receptor protein $\mathrm{p} 55$ in serum from pregnant women at term (Fig. 1). In contrast, p55 was not detected in the serum samples from fertile, nonpregnant control women (Fig. 1). These results are in accordance with those obtained when urine samples from pregnant and nonpregnant women were examined for TNFR in a previous study; 555 was detected in urine from the pregnant group exclusively (35). Taken together, these data suggest that $I$ ) a normal pregnancy in humans is associated with an increased release of p55 into the maternal circulation, and 2) increased levels of p 55 in urine are suggestive of the concomitant presence of $\mathrm{p} 55$ in serum.

The presence of soluble TNFR in normal pregnancy appeared not to be restricted to the maternal organism exclusively, as neonatal serum taken during the first $24 \mathrm{~h}$ after delivery contained high levels of p55 (Fig. 1). The data from the neonatal serum analysis must, however, be interpreted carefully, inasmuch as the blood samples were obtained from sick, hospitalized neonates. On the other hand, high levels of $\mathrm{p} 55$ were also detected in first-voided urine samples from healthy newborns, supporting the conclusion that a normal human pregnancy does comprise a fetal exposure to soluble TNF- $\alpha$ receptors.

The urine levels of p 55 were significantly higher in the neonatal period than later in childhood (Fig. 2). The variations in p55 levels between groups of children at different ages might be due to changes in renal function occurring throughout childhood. However, even when renal function was taken into consideration by calculating the ratio between $\mathrm{p} 55$ and the urine protein concentration $(R / p 55)$ (Table 1$)$, urine p55 was significantly higher during the neonatal period than later in childhood. However, before conclusions can be drawn, it must be remembered that the examined neonatal samples were collected at the Neonatal Department, i.e. from sick children. Knowledge is sparse about the role of soluble TNFR in neonatal pathophysiology. It is well known that increased expression of TNFR on cell membranes may be induced by various inflammatory mediators, such as bacterial lipolysaccharide $(33,38)$ and interferon $(39)$, whereas
TNFR expression is down-regulated by TNF- $\alpha$ (40). IL-6 (41, 42), but not TNF- $\alpha$ (42), has been detected in raised concentrations in serum from neonates suffering from septicemia. However, no studies have demonstrated that shedding of soluble TNFR is increased by the exposure of inflammatory cytokines, and we observed no correlation between the concentration of p 55 and the levels of biologically active cytokines (TNF- $\alpha$, IL-1, IL-6) in amniotic fluid from women in delivery at term (unpublished experiments). To conclude, the reduced $\mathrm{p} 55$ levels in urine after the neonatal period compared with those of both the healthy newborn babies and the hospitalized neonates are suggestive of a postpartum renal elimination of the soluble TNFR shed during pregnancy. Further studies are needed to make final interpretations about the time course required for this neonatal elimination under nonpathologic conditions.

The present data support the conclusion that a normal human pregnancy is associated with an increased shedding of soluble TNF- $\alpha$ receptors (p55), which are distributed both in the maternal and the fetal organism. No conclusions can be drawn here as to whether the receptors are shed from the maternal organism, the fetus, or the placenta. Several in vitro studies suggest ubiquitous occurrence of membrane-associated TNFR $(21,22,43)$, but sparse information is yet available about the cellular distribution of receptors for TNF- $\alpha$ in human tissues in vivo. Membrane preparations from placenta have been reported to have a high TNF- $\alpha$ binding capacity (44), thus suggesting that TNFR are expressed by placental cells. In a previous study, we reported the detection of an abundant expression of $\mathrm{p} 55$ by the villous syncytiotrophoblasts in placenta at term (45), and we have recently detected soluble TNFR in supernatants from placental cell cultures (unpublished experiments). Considered together, these observations make placental tissue a likely candidate as a cellular source for the $\mathrm{p} 55$ shed during pregnancy. However, the precise origin of the $p 55$ shed during pregnancy remains an open question. Furthermore, whether the soluble TNF- $\alpha$ receptors influence TNF- $\alpha$ activity and contribute to the well being of the fetus remains to be elucidated.

Acknowledgments. The authors thank the nurses at the Delivery Department and the Neonatal Department for collecting the materials. Without their cooperation and commitment, this project could not have been carried out. We appreciate the support given by the staff at the laboratory in the Children's Department. We thank Manfred Brockhaus, Hansruedi Loetscher, and Werner Lesslauer (Central Research Units, F. Hoffman-La Roche) for supplying the MAb htr 5, htr 9, utr 1, and utr 4 and the rTNFR. The statistical assistance of Harald Johnsen is gratefully acknowledged, and we appreciate the help of Dagmar Moholdt in preparing the manuscript.

\section{REFERENCES}

1. Hunt JS 1989 Cytokine networks in the uteroplacental unit: macrophages as pivotal regulatory cells. J Reprod Immunol 16:1-17

2. Wegmann TG 1989 The cytokine basis for the cross-talk between the maternal immune and reproductive system. Curr Opin Immunol 2:765-769

3. Toder V, Kochavi E, Altaratz H, Gleicher N 1989 Growth factors as stimulators of placental growth. Placenta 10:458

4. Old LJ 1989 Tumor necrosis factor. Sci Am 258:41-49

5. Beutler B, Cerami A 1988 Tumor necrosis, cachexia, shock and inflammation: a common mediator. Annu Rev Biochem 57:505-518

6. Jaattela M, Kuusela P, Saksela E 1988 Demonstration of tumor necrosis factor in human amniotic fluids and supernatants of placental and decidual tissues. Lab Invest 58:48-52

7. Starkey PM, Vince G, Shorter SC, Sargent IL, Redman CWG 1989 The synthesis of tumor necrosis factor by human placental and decidual tissue. Placenta 10:487A(abstr)

8. Berkowitz RS, Faris HMP, Hill JA, Anderson DJ 1990 Localization of leukocytes and cytokines in chorionic villi of normal placentas and complete hydatiform moles. Gynecol Oncol 37:396-400

9. Berkowitz RS, Hill JA, Kurtz CB, Anderson DJ 1988 Effects of products of activated leukocytes (lymphokines and monokines) on the growth of malignant trophoblast cells in vitro. Am J Obstet Gynecol 158:199-203

10. Hunt JS, Soares MJ, Lei M-G, Smith RN, Wheaton D, Atherton RA, Morrison DC 1989 Products of lipopolysaccharide-activated macrophages (tumor ne- 
crosis factor $-\alpha$, transforming growth factor- $\beta$ ) but not lipopolysaccharide modify DNA synthesis by rat trophoblast cells exhibiting the $80-\mathrm{kDa}$ lipopolysaccharide-binding protein. J Immunol 143:1606-1613

11. Maury CPJ, Teppo AM 1987 Raised levels of cachectin/tumor necrosis factor $\alpha$ in a renal allograft rejection. J Exp Med 166:1132-1137

12. Shalaby MR, Fendly B, Sheehan KC, Schreiber RD, Ammann AJ 1989 Prevention of the graft-versus-host reaction in newborn mice by antibodies to tumor necrosis factor-alpha. Transplantation 47:1057-1061

13. Silen ML, Firpo A, Morgello S, Lowry SF, Francus T 1989 Interleukin-1 $\alpha$ and tumor necrosis factor $\alpha$ cause placental injury in the rat. Am J Pathol 135 239-244

14. Rieder RF, Thomas L 1960 Studies on the mechanisms involved in the production of abortion by endotoxin. J Immunol 84:189-193

15. Parant M 1990 Possible mediators in endotoxin-induced abortion. Res Immunol 141:164-168

16. Romero R, Manongue KR, Mitchell MD, Phil D, Wu YK, Oyarzun E, Hobbins JC, Cerami A 1989 Infection and labor. 4. Cachectin-tumor necrosis factor in the amniotic fluid of women with intraamniotic infection and preterm labor. Am J Obstet Gynecol 161:336-341

17. Casey ML, Cox SM, Beutler B, Milewich L, MacDonald PC 1989 Cachectin/ Tumor necrosis factor- $\alpha$ formation in human decidua. Potential role of cytokines in infection-induced preterm labor. J Clin Invest 83:430-436

18. Aggarwal BB, Eessalu TE, Hass PE 1985 Characterization of receptors for human tumor necrosis factor and their regulation by $\gamma$-interferon. Nature 318:665-667

19. Old LJ 1988 Tumor necrosis factor. Sci Am 258:41-49

20. Creasey AA, Yamoto R, Vitt CR 1987 A high molecular weight component of the human tumor necrosis factor receptor is associated with cytotoxicity. Proc Natl Acad Sci USA 84:3293-3297

21. Brockhaus M, Schonfeld HJ, Schlager EJ, Hinziker W, Lesslauer W, Loetscher H 1990 Identification of two kinds of TNF receptors on human cell lines by monoclonal antibodies. Proc Natl Acad Sci USA 87:3127-3131

22. Hohmann H-P, Remy R, Brockhaus M, van Loon APGM 1989 Two different cell types have different major receptors for human tumor necrosis factor. J Biol Chem 264:14 927-14 934

23. Loetscher H, Pan Y-CE, Lahm H-W, Gentz R, Brockhaus M, Tabuchi H Lesslauer W 1990 Molecular cloning and expression of the human $55 \mathrm{kD}$ tumor necrosis factor receptor. Cell 61:351-359

24. Schall TJ, Lewis M, Koller KJ, Lee A, Rice GC, Wong GHW, Gatanaga T, Granger GA, Lentz R, Raab H, Kohr WJ, Goeddel DV 1990 Molecular cloning and expression of a receptor for human tumor necrosis factor. Cell 61:361-370

25. Smith CA, Davis T, Anderson D, Solam L, Beckmann MP, Jerzy R, Dower SK, Cosman D, Goodwin RG 1990 A receptor for human tumor necrosis factor defines an unusual family of cellular and viral proteins. Science 248 : 1019-1923

26. Engelmann H, Aderka D, Rubinstein M, Rotman D, Wallach D 1989 A human tumor necrosis factor-binding protein purified to homogeneity from human urine protects from tumor necrosis factor toxicity. J Biol Chem 264 $11974-11978$
27. Seckinger P, Isaaz S, Dayer J-M 1988 A human inhibitor of tumor necrosis factor $\alpha$. J Exp Med 167:1511-1516

28. Nophar Y, Kemper O, Brakebusch C, Engelmann H, Zwang R, Aderka D, Holtmann H, Wallach D 1990 The c-DNA for the type 1 TNF-R, cloned using amino acid sequence data of its soluble form, encodes both the cell surface and a soluble form of the receptor. EMBO J 9:65-74

29. Poteu F, Nathan C 1990 Shedding of tumor necrosis factor receptors by activated human neutrophils. J Exp Med 172:599-607

30. Olsson I, Lantz M, Nilsson E, Peetre C, Thysell H, Grubb A, Adolf G 1989 Isolation and characterization of a tumor necrosis factor binding protein from urine. Eur J Haematol 42:270-275

31. Widmer MB, Grabstein $\mathrm{KH}$, Jacobs CA, Lynch DH, Maliszewski CR, Mohler KM, Fanslow WC 1991 Soluble cytokine receptors as immune response modifiers. J Cell Biochem (suppl) 15F:33

32. Owen Schaub LB, Crump WL, Morin GI, Grimm EA 1989 Regulation of lymphocyte tumor necrosis factor receptors by IL 2. J Immunol 143: 2236-2241

33. Ding AH, Sanchez E, Srimal S, Nathan CF 1989 Macrophages rapidly internalize their tumor necrosis factor receptors in response to bacterial lipopolysaccharide. J Biol Chem 264:3924-3929

34. Wladimiroff JW, Campell S 1974 Fetal urine production rates in normal and complicated pregnancy. Lancet 1:151-154

35. Austgulen R, Liabakk N-B, Brockhaus M, Espevik T 1992 Soluble TNF receptors in amniotic fluid and in urine from pregnant women. $J$ Reprod Immunol 22:105-116

36. Liabakk N-B, Sundan A, Waage A, Brockhaus M, Loetscher H, Lesslauer W, Espevik T 1991 Development of immuno-assays for the detection of soluble TNF receptors. J Immunol Methods 141:237-243

37. Tuck S 1989 Fluid and electrolyte balance in the neonate. In: Roberton NRC (ed) Textbook of Neonatology. Churchill-Livingstone, New York, pp 162 177

38. Gatanaga T, Hwang C, Gatanaga M, Cappuccini F, Yamamoto RS, Grange GA 1991 The regulation of TNF receptor mRNA synthesis, membrane expression, and release by PM regulated human monocytic THP-1 cells in vitro. Cell Immunol 138:1-10

39. Tsujimoto M, Yip YK, Vilcek J 1986 Interferon gamma enhances expression of cellular receptors for tumor necrosis factor. J Immunol 136:2441-2444

40. Tsujimoto M, Vilcek $\mathbf{J} 1987$ Tumor necrosis factor-induced downregulation of its receptors in HeLa cells. J Biochem 102:1571-1577

41. Buck C, Bundschuh J, Gallati H, Bartmann P, Pohlandt F 1992 Interleukin 6 (IL-6): a very early indicator of neonatal septicemia. Pediatr Res 31 : 274A(abstr)

42. Harris MC, Kilpatrick L, Sullivan J, Dulkerian S, McCawley L, Corcoran L, Butler S, Costarino AT 1992 Elevations of interleukin 6 in neonatal sepsis and necrotizing enterocolitis (NEC) Pediatr Res 31:204A(abstr)

43. Espevik T, Brockhaus M, Loetscher H, Nonstad U, Shalaby R 1990 Charac terization of binding and biological effects of monoclonal antibodies agains a human tumor necrosis factor receptor. J Exp Med 171:415-426

44. Eades DK, Cornelius P, Pekala PH 1988 Characterization of the tumor necrosis factor receptor in human placenta. Placenta 9:247-251

45. Austgulen R, Espevik T, Mecsei R, Scott H 1992 Expression of receptors for tumor necrosis factor in human placenta at term. Acta Obstet Gynecol Scand $71: 417-424$ 